\title{
SOME CRITICAL OBSERVATIONS ON THE INTER- NATIONAL LAW COMMISSION'S DRAFT ARTICLES ON STATE RESPONSIBILITY
}

\author{
Ando Nisuke*
}

\section{INTRODUCTION}

By the end of its forty-seventh session in July 1995, the International Law Commission (hereafter ILC) had adopted some fifty-six draft articles on the topic of State Responsibility. ${ }^{1}$ The first thirty-five articles, which had been provisionally adopted on first reading in 1980 , constitute Part One of the draft and deal with "the origin of international responsibility". The next fourteen, which have been provisionally adopted so far, constitute Part Two and deal with the "content, forms and degree of international responsibility". ${ }^{3}$ In addition, at its forty-seventh session the Commission adopted seven more draft articles which should be included in Part Three dealing with "Dispute settlement procedures". ${ }^{4}$

The draft as a whole has not been completed, despite the fact that more than forty years have passed since the Commission started its work on the topic in $1955 .^{5}$ However, considering that Part One forms the basis of the entire draft and that all of the thirty-five draft articles of Part One have been adopted with commentaries, it may be worthy of some observations. ${ }^{6}$ This paper attempts to point to some problems concerning the basic premises as

\footnotetext{
* Professor of International Law, Faculty of Law, Kyoto University, Japan.

${ }^{1}$ Report of the International Law Commission on the Work of its Forty-Seventh Session 2 May-21 July 1995, GAOR, Fiftieth Session, Supp. No. 10 (A/50/10) paras. 235, 340-342 and 364. The number (56) includes Article 11 of Part Two for which no commentary has been adopted yet. It does not include Articles 1 and 2, which are attached to the Annex to Part Three.

${ }^{2}$ Ibid., para. 232.

${ }^{3}$ Ibid., paras. 232 and 235.

${ }^{4}$ Ibid., paras. 233, 236 and 364.

${ }^{5}$ YbILC 1955, Vol. I, p. 190 para. 2.

${ }^{6}$ In fact, a number of observations have been published. See, for example, M. SPINEDI \& B. Simma (Eds.), United Nations Codification of State Responsibility (1987).
}

Asian Yearbook of International Law, Volume 5 (Ko Swan Sik et al., eds.; 90-411-0375-9

() 1997 Kluwer Law International; printed in the Netherlands), pp. 125-144 
well as the content of the draft articles of Part One, but before discussing the issues, a quick look into the history of the draft seems to be in order.

\section{A SUMMARY HISTORY OF THE DRAFT ARTICLES}

When the ILC adopted a list of fourteen topics for codification in 1949, "State Responsibility" was included among them together with "Treatment of Aliens". ' F.V. GARCÍA-AMADOR, who was nominated as Special Rapporteur for the topic of state responsibility in $1955,{ }^{8}$ submitted six reports before his membership of the Commission expired in $1960 .{ }^{9}$ Of particular interest were the revised draft articles attached to his last report, entitled "Responsibility of the State for injuries caused in its territory to the person or property of aliens". ${ }^{10}$ The draft consisted of twenty-seven articles and, as the title suggested, it comprised both substantive rules concerning the treatment of aliens by a state and procedural rules concerning implementation of responsibility which results from a state's violation of those substantive rules. GARCÍAAMADOR's approach to the topic was a traditional one in that it dealt only with the responsibility of a state for violation of its obligations with respect to the treatment of aliens in its territory. ${ }^{11}$

For a variety of reasons, the ILC did not spend much time on discussing GARCÍA AMADOR's reports. In 1962, the Commission established a subcommittee of ten, headed by R. AGO, whose mandate was to discuss general questions relating to its work on the topic of state responsibility and to report to the Commission's next session about the directives to be given to a new Special Rapporteur. ${ }^{12}$ During the sub-committee's discussions, some members emphasized that the study on the topic should begin with a well-defined sector such as state responsibility for injuries to aliens, while others argued that the issue of specific rules concerning the treatment of aliens should not be confused with the issue of general rules on state responsibility resulting from a violation of any substantive rule of international law and that the Commission

\footnotetext{
7 YbILC 1949, p. 190 para. 69.

${ }^{8}$ YbILC 1955, Vol. I, p. 190 para. 2.

${ }^{9}$ YbILC 1956, Vol. II, p. 173 et seq.; YbILC 1957, Vol. II, p. 104 et seq.; YbILC 1958, Vol. II, p. 47 et seq.; YbILC 1959, Vol. II, p. 1 et seq.; YbILC 1960, Vol. II, p. 40 et seq.; YbILC 1961, Vol. II, p. 1 et seq.

${ }^{10}$ Ibid. 1961, Vol. II, p. 46 et seq.

${ }^{11}$ For the past codification attempts attached to GARCÍA-AMADOR's initial report, see YbILC 1956, Vol. II, p. 176-180 and 221 et seq.

${ }^{12}$ YbILC 1962, Vol. I, p. 45 paras. 1-5 (637th meeting); YbILC 1963, Vol. II, p. 227.
} 
should deal with these general rules. ${ }^{13}$ In the end the latter argument prevailed, and on the basis of the sub-committee's report the ILC decided to adopt a new approach to the topic of state responsibility. ${ }^{14}$ It marked a drastic departure from the traditional approach endorsed by GARCÍA-AMADOR's draft.

The characteristics of the new approach may be summarized as follows:

(1) The ILC should codify general rules governing international responsibility of a state, that is, the responsibility arising from a violation, not of specific rules such as those related to the treatment of aliens, but of any rule, conventional or otherwise, of international law. Those general rules mean "the rules which govern all the new legal relationships that may follow an internationally wrongful act of a state, regardless of the particular sector to which the rule violated by the act may belong"; ${ }^{15}$

(2) The Commission divided all the rules of international law into two types - 'primary' or 'secondary' rules - and decided that it should deal exclusively with secondary rules in codifying the general rules on state responsibility. Primary rules mean those rules which impose specific obligations on a state in one or another sector of inter-state relations, while secondary rules are the rules which are concerned with determining the legal consequences of failure to fulfil obligations established by primary rules; ${ }^{16}$ and

(3) accordingly, the draft to be codified should relate only to the responsibility of a state for internationally wrongful acts, that is, the responsibility of a state for a violation of primary rules. In other words, the draft would exclude the question of liability for injurious consequences arising from internationally lawful acts. ${ }^{17}$

\section{SOME PROBLEMS OF THE DRAFT ARTICLES}

\subsection{Problems concerning Basic Premises}

The above three characteristics of the new approach may be regarded as 'basic premises' on which the ILC has developed its codification work. However, in this writer's view, all the three premises are not free from problems.

\footnotetext{
${ }^{13}$ YbILC 1963, Vol. II, pp. 227-228 para. 4.

${ }^{14}$ Ibid., p. 228 para. 6.

${ }^{15}$ YbILC 1973, Vol. II, p. 170 para. 42.

${ }^{16}$ Ibid., p. 169 para. 40.

${ }^{17}$ Ibid., p. 169 para. 38. As a matter of fact, the ILC decided in 1979 to take up the matter for codification and has been working on it since.
} 


\subsubsection{General Rules of Responsibility and Responsibility for Specific Issues}

It is true that the traditional rules of international law concerning state responsibility have evolved around the question of responsibility of a state for injuries caused in its territory to the person or property of aliens. ${ }^{18}$ At the same time it has long been recognized that the question of state responsibility does arise not only from a violation of a state's obligations with respect to the treatment of aliens but also from a violation of any other obligation under international law. In fact, during the 1949 discussions of the ILC on the choice of topics for codification, G. SCELLE pointed out that the question of state responsibility would recur constantly during the study of the majority of the subjects which the Commission had already placed on the list of topics for codification. ${ }^{19}$ Thus, it is not without reason that the Commission switched in 1962 from the traditional approach of GARCÍA-AMADOR to the current approach of codifying general rules of state responsibility for a violation of any rules of international law.

Some of the draft articles of Part One are stipulated in such general and abstract terms that it is difficult to grasp their implications. For example, Article 1 provides, "Every internationally wrongful act of a State entails the international responsibility of that State". According to the commentary of the Commission, Article 1 is intended, first, to state the basic rule of state responsibility. Secondly, it is intended to cover every kind of new relations resulting from an internationally wrongful act of a state, whether such relations are limited to the offending state and the injured state or extend to other subjects of international law as well. Thirdly, Article 1 is intended to clarify that the offending state does incur international responsibility. Fourthly, it is intended not to admit any exception to the basic rule that an internationally wrongful act of a state involves the international responsibility of that state. Lastly, Article 1 is intended to avoid the formula which may suggest that international responsibility results exclusively from a wrongful act, thus leaving room for the existence of liability for a lawful act. ${ }^{20}$ All these intentions are important, but it is extremely difficult to read all of them into the very general and abstract stipulation of Article 1.

In a similar vein, Article 2 provides, "Every State is subject to the possibility of being held to have committed an internationally wrongful act entailing its international responsibility". Again, the commentary explains that the

\footnotetext{
${ }^{18}$ See the title of GARCÍA-AMADOR's last report.

19 YbILC 1949, p. 50 para. 32.

${ }^{20}$ YbILC 1973, Vol. II, pp. 175-176 paras. 9-13.
} 
Article deals with what domestic law terms 'delictual capacity' or 'capacity to commit wrongful acts'. It is intended, according to the commentary, to ensure that a violation of an international obligation committed by a member state of a federal state is attributable to the latter even in case the former possesses international personality. Article 2 is also intended to cover the situation where an organ of a state commits internationally wrongful acts in the territory of another state. In such eventuality the article is so stipulated as to render not the territorial state but the state of that organ responsible under international law. ${ }^{21}$ The provisions of some other articles of Part One, namely Article 7 paragraph 1 and Article 12 paragraph 1 , clarify these intentions, but considering that the commentary does not constitute part of the draft articles, it is almost impossible to read these intentions into the general and abstract stipulations of Article 2.

When the ILC discussed the first three draft articles contained in AGO's second report, KEARNEY noted that, while the Special Rapporteur was proposing a number of general rules on the abstract aspects of state responsibility, rules limited to pure, abstract responsibility might prove to be too metaphysical for the kind of international society that existed in the contemporary world. ${ }^{22}$ Already in 1962 during the discussion of the above-mentioned sub-committee, BRIGGS pointed out that the scarcity of materials on the aspects of state responsibility, except in the field of treatment of aliens, would necessitate the Commission's work to be in the nature of legislation rather than codification and that AGO's proposal for the outline of work was a little too abstract. ${ }^{23}$ Later MCDOUGAL was to say, "The . . recent work of the [International Law] Commission has been at such a high level of abstraction as to shed but a dim light upon specific controversies." 24

In this connection it might be useful to have a glimpse of the responsibility system in domestic law. For example, responsibility for an act of an individual is roughly divided into either criminal or civil responsibility, depending upon the nature of the act in question. The methods of attributing responsibility are respectively regulated by rules of criminal or civil procedure. Civil responsibility is further divided into responsibility in family matters and responsibility in property matters. The latter is again divided into responsibility for tort and responsibility for contract, and the change of social circumstances as well as the development of technology requires the evolution of new types of responsi-

${ }^{21}$ Ibid., pp. 177-178 paras. 2 and 5-6.

22 YbILC 1970, Vol.I, p. 217 para. 32.

${ }^{23}$ YbILC 1963, Vol.II, p. 231.

${ }^{24}$ M.S. McDougal, H.D. Lasswell \& L. Chen, Human Rights and World Public Order (New Haven: Yale University Press, 1980) p. 762 n. 92. 
bility with corresponding methods of attribution and discharge. Compared with these various types of responsibility in domestic law, responsibility in international law is far more simple. Nevertheless, the ILC draft Article 19 divides internationally wrongful acts into international crimes and international delicts, and if an attempt is made to codify general rules covering both categories of acts, then their formulation is likely to be general in nature and abstract in content. It is indeed questionable whether a convention composed of provisions of such general and abstract terms would prompt states to convene an international conference for its adoption, but the ILC should have been aware of this possibility when it decided to codify 'general' rules of state responsibility in 1962.

\subsubsection{Primary Rules and Secondary Rules}

While the ILC divides the rules of international law into primary or secondary rules, ${ }^{25}$ the distinction between the two categories is not always clear. Furthermore, it is doubtful what practical merits entail from the categorical distinction between the two types of rules.

The question of compensation for nationalization of private foreign property is a case in point. It is generally agreed that, in the absence of treaty provisions to the contrary, nationalization of such property is lawful on condition that (1) it serves a public purpose of the nationalizing state and (2) the measures of nationalization are not discriminatory. But there is a difference of views as to whether the payment of compensation for the nationalized property is a third condition for the lawfulness of nationalization. ${ }^{26}$ According to those who consider it to constitute the third condition, the payment of compensation should be regarded as a primary rule, whereas it should be regarded as a secondary rule in the view of those who consider the payment not to be a condition of lawfulness but merely a legal consequence of nationalization. It might be added that state practice does not seem to provide a clear-cut indication as to whether the payment of compensation belongs to a primary or a secondary rule. ${ }^{27}$

\footnotetext{
${ }^{25}$ See supra.

${ }^{26}$ Compare, in this respect, the 1958 resolution of the International Law Association (hereafter ILA) and the statement of R. DELSON prior to the adoption of that resolution. ILA, Report of the Forty-Eighth Conference (New York, 1958) pp. xi \& 155 respectively. See also, ibid., pp. 161-183.

${ }^{27}$ Encyclopedia of Public International Law, Instalment 8 (Max Planck Institute for Comparative Public Law and International Law; Amsterdam: North-Holland, 1981) pp. 218-219.
} 
This case also suggests that secondary rules are closely linked to primary rules. When the ILC discussed AGO's second report in 1970, REUTER pointed out that, although responsibility might be held to have a derived secondary character, a very large part of responsibility lay in failure to comply with what were called 'standards' in English ${ }^{28}$ referring to the standards of treatment of aliens which concern primary rules. While expressing appreciation for the Special Rapporteur's report, ELIAS warned that the intellectual effort which had gone into the report might lead to emphasizing distinctions of which the international community might not be fully aware. ${ }^{29}$ ROSENNE, too, expressed doubt whether the distinction between primary and secondary rules described in the report could be fully and consistently maintained. He was not certain that imputability would operate in an identical way, regardless of the content of the primary rule, non-observance of which was the generator of responsibility. ${ }^{30}$

Indeed, the following examples typically illustrate the link between primary and secondary rules. A material breach of a bilateral treaty by one state party entitles the other state party to invoke its termination or suspension. ${ }^{31}$ When diplomatic privileges are abused by a member of a diplomatic mission, the sending state may waive the immunity from the receiving state's jurisdiction for that member, or the receiving state may notify the sending state that the member is persona non grata. ${ }^{32} \mathrm{~A}$ prisoner of war may be brought to trial before a domestic court of the enemy state with respect to a violation of laws of war committed by him prior to his capture..$^{33}$ In all these cases primary rules dictate secondary rules, or, to put it the other way round, the application of a secondary rule is contingent upon the violation of a specific primary rule, and this is not an unusual phenomenon in international law. Reflecting on AGO's remark that any effort to combine rules of substance and rules of procedure might lead to dangerous confusion, ROSENNE contended that the development of substantive international law was bound to demonstrate more clearly the need for parallel development of the international law of procedure. ${ }^{34}$

If so, what practical merits can be expected to derive from a rigid separation of secondary from primary rules? According to BAXTER:

"The circumstances under which responsibility attaches and the remedies to be provided for violations of the rules of law cannot be divided from the

\footnotetext{
${ }^{28}$ YBILC 1970, Vol. 1, p. 188 para. 8.

${ }^{29}$ Ibid., p. 221 para. 76.

${ }^{30}$ Ibid., p. 220 para. 58.

${ }^{31}$ Vienna Convention on the Law of Treaties, Art. 60 para. 1.

${ }^{32}$ Vienna Convention on Diplomatic Relations, Art. 9 para. 1 and Art. 32 para. 1.

${ }^{33}$ Encyclopedia of Public International Law, Instalment 4, pp. 296-297.

${ }^{34}$ YBILC 1970, Vol.I, p. 221 para. 68.
} 
substantive rules of conduct themselves. The nature of responsibility will vary with the nature of the rule violated. The remedy, the reparation, will likewise vary according to the rule violated, the responsibility engaged, and the procedure followed in seeking vindication of the wrong.",35

Consequently, a codification of exclusively secondary rules, as detached from corresponding primary rules, is most likely to end up with mere enumeration of various procedural rules to attribute and discharge responsibility. In fact, the ILC's work on Part Two of state responsibility seems to be proving that possibility. It is again doubtful if states are persuaded to hold an international conference in order to adopt a convention composed of such enumeration of secondary rules.

\subsubsection{Responsibility for Wrongful Acts and Liability for Lawful Acts}

The third premise of the ILC's work on state responsibility is that it should deal only with responsibility for internationally 'wrongful' acts, as distinguished from liability for injurious consequences of 'lawful' acts. Indeed, since 1979 , the ILC has been working on the topic of "International Liability for Injurious Consequences Arising out of Acts not Prohibited by International Law" ${ }^{36}$ However, there are cases where the distinction between responsibility for wrongful acts and liability for lawful acts is not clear. As a result, practical merits of the distinction are not certain either.

Reference has already been made to the payment of compensation for nationalization of private foreign property. ${ }^{37}$ If such payment is considered one of the conditions for the lawfulness of nationalization, non-payment of compensation makes nationalization unlawful, thus entailing state responsibility for a wrongful act. However, if payment of compensation is not a condition for lawfulness but merely a legal consequence of nationalization, then the issue of payment falls under the topic of liability for lawful acts. Of course, in the latter view, if the nationalizing state refuses to pay the compensation, such refusal itself will constitute a failure to fulfil its obligation and entail responsibility of that state. It must be asked, however, what practical merits exist in distinguishing responsibility for wrongful acts from liability for lawful acts.

\footnotetext{
${ }^{35}$ R.R. BAXTER, 'Reflections on Codification in Light of the International Law of State Responsibility for Injuries to Aliens', 16 Syracuse Law Review (1965) p. 748.

${ }^{36}$ See supra.

${ }^{37}$ See supra.
} 
The relevance of the distinction is explained by the ILC as follows:

\begin{abstract}
"The Commission fully recognizes the importance, not only of questions of responsibility for internationally wrongful acts, but also of those concerning the obligation to make good any harmful consequences arising out of certain lawful activities, especially those which because of their nature present certain risks. The Commission takes the view, however, that questions in this latter category should not be dealt jointly with those in the former category. In view of the entirely different basis of the liability for risk and the different nature of the rules governing it, as well as its content and the form it may assume, a joint examination of the two subjects could only make both of them more difficult to grasp." 38
\end{abstract}

Nevertheless, the Commission's discussion on draft Article 23 concerning "Breach of an international obligation to prevent a given event" illustrates the circumstances where it is difficult to distinguish the two.

AGO's original draft Article 23 provided: “There is no breach by a State of an international obligation requiring it to prevent a given event unless, following a lack of prevention on the part of the State, the event in question occurs." ${ }^{39}$ When the draft was introduced to the Commission, REUTER stated that he would personally prefer an interpretation based on the idea that, when the risk could not be calculated in advance, it could be judged only by its effect in the light of the material damage caused. In his opinion, since the risk would not have been apparent before the material damage occurred, the obligation to prevent the risk would not have been apparent either. ${ }^{40}$ Similarly, DIAZ GONZÁLEZ feared that the wording of the draft as it stood left him in doubt as to whether there were any limitations on the obligation of the state to prevent a given event from occurring. Citing the case where a visiting head of a foreign state was attacked despite all the necessary precautions of the receiving state, he considered that the only obligation of the latter state in such a case was to apprehend and prosecute the attacker and that it could not be held responsible for the occurrence of attack itself. ${ }^{41}$ On that occasion AGO explained that draft Article 23 was not to provide for absolute obligations and should exclude the case where the event occurred despite the fact that the state had taken adequate preventive measures. ${ }^{42}$ The fear expressed by DIAZ GONZÁLEZ is partly due to the difficulty of defining the scope of preventive

\footnotetext{
38 YBILC 1975, Vol. II, p. 54 para. 33.

${ }^{39}$ YbILC 1978, Vol. II Pt. One, p. 37 para. 19.

${ }^{40}$ Ibid., Vol.I, p. 7 para. 23.

${ }^{41}$ Ibid., p. 9 paras. $1-2$.

${ }^{42}$ Ibid. pp. 9-10 para. 4.
} 
obligations, but it is also due to the difficulty of distinguishing responsibility for wrongful acts from liability for lawful acts.

AKEHURST, who was critical of the ILC's approach to the topic of "International Liability for Injurious Consequences Arising out of Acts not Prohibited by International Law", had the following to say:

"Since compensation is also [. . .] payable for wrongful acts, it may be wondered whether there is any real difference between a duty to pay compensation for a lawful act and a duty to pay compensation for a wrongful act. It is submitted, however, that the distinction is important for two reasons. First, the amount of compensation payable for a lawful act is probably less than the amount of compensation payable for a wrongful act [...]

The second point is that a certain stigma attaches to the commission of an unlawful act. States may therefore be reluctant to pay compensation for wrongful acts because they are unwilling to admit that they have done anything wrong. They may be more willing to pay compensation for lawful acts, because such payments do not imply a confession of wrongdoing [ . . ]." ${ }^{.43}$

He then concluded that "in other respects liability for lawful acts is similar to liability for wrongful acts". ${ }^{44}$ There may not be a universal acceptance of AKEHURST's conclusion, but the fact remains that practical merits of distinguishing responsibility for wrongful acts from liability for lawful acts are not at all certain.

Since 1985 BARBOZA was the Special Rapporteur for the ILC's work on the topic of liability for lawful acts. In an article published in 1988, he emphasized that responsibility for risk (la responsabilité (causale)) was not an exception to responsibility for wrongful acts but that the two responsibilities represented different aspects of a larger category (genre) ${ }^{45}$ As a matter of fact, in one of its annual reports relating to state responsibility the ILC does not deny a degree of 'overlap' of the obligation of a state for reparation resulting from its wrongful acts with its obligation to pay compensation for injurious consequences arising from lawful acts. ${ }^{46}$ Neither does that report deny a degree of 'overlap' of a state's obligation to compensate for injurious consequences of lawful acts with its obligation for reparation resulting from acts whose wrongfulness is precluded under the provisions of Part One (Art.

\footnotetext{
${ }^{43}$ M.B. AKEHURST, 'International Liability for Injurious Consequences Arising out of Acts not Prohibited by International Law', 16 Netherlands Yearbook of International Law (1985) pp. 14-15.

${ }^{44}$ Ibid. p. 16.

${ }^{45} \mathrm{~J}$. BARBOZA, 'La responsabilité (causale) à la Commission du Droit International', 34 Annuaire Français de Droit International (1988) pp. 520-522.

${ }^{46}$ YBILC 1980, Vol. II Pt. Two, p. 62 para. 42.
} 
29: consent of the injured state; Art. 31: force majeure and fortuitous event; Art. 32: distress; and Art. 33: state of necessity). ${ }^{47}$

\subsection{Problems concerning the Content of the Draft Articles}

The thirty-five draft articles on state responsibility adopted by the ILC, which constitute Part One dealing with "origin of international responsibility", are not free from problems in their content either. For example, it is questionable whether the list of enumerated "circumstances precluding wrongfulness" is an exhaustive one. It is also not clear whether some of these circumstances overlap with each other. ${ }^{48}$ In this paper special attention will be drawn to the following three issues: (1) the distinction between 'international crimes' and 'international delicts' as stipulated in Article 19 and the relevance of the distinction to the provisions of Part Two; (2) the relation between 'obligation of conduct' and 'obligation of result' as reflected in Articles 20-23; and (3) the time factor concerning 'complex acts'.

\subsubsection{Distinction between International Crimes and International Delicts and its Relevance to the Provisions of Part Two}

Draft Article 19 divides internationally wrongful acts into two categories - international crimes and international delicts - and defines an international crime as an "act which results from the breach by a State of an international obligation so essential for the protection of fundamental interests of the international community that its breach is recognized as a crime by that community as a whole". As examples of international crimes, the Article refers to aggression, colonial domination, slavery, genocide, apartheid and massive pollution of the environment. An international delict is "any internationally wrongful act which is not an international crime" as defined above. The question that may be raised concerns the propriety of dividing internationally wrongful acts into the two categories as well as the relevance of such distinction to the provisions

\footnotetext{
${ }^{47}$ Ibid.

${ }^{48}$ See, for example, the remarks of RIPHAGEN and NJENGA in YBILC 1979, Vol. 1, p. 196 para. 1 et seq. and p. 203 para. 9 et seq. See also, A. GATtini, Zufall und Force Majeure im System der Staatsverantwortlichkeit anhand der ILC-Kodifikationsarbeit (Berlin: Dunker Humblot, 1991); J. BARBOZA, 'Necessity (Revisited) in International Law', in J. MAKARCZYK (Ed.), Essays in International Law in Honour of Judge Manfred Lachs (The Hague: Martinus Nijhoff, 1984), p. 27 et seq.; and J.J.A. SALMON, 'Faut-il codifier l'état de nécessité en droit international?', in ibid., p. 235 et seq.
} 
of Part Two where the ILC should deal with "the content, forms and degree of international responsibility".

Earlier in 1976, when AGO submitted draft Article 19 (originally Article 18) for consideration by the ILC, he emphasized the necessity of distinguishing among different kinds of internationally wrongful acts on the basis of the importance of the obligations breached, stating that the distinction between simple offenses and "international crimes" should entail consequences with respect to the subject entitled to demand compliance with the rules of international law and with respect to the forms of responsibility as well. ${ }^{49}$ YASSEEN argued that, since the obligations of the two categories were not of equal weight, a special regime of responsibility should apply to the breach of obligations of vital interest to the international community. ${ }^{50}$ In line with YASSEEN, SETTE CAMARA referred to the redress under Chapter VII of the United Nations Charter as a prospective content of such special regime, ${ }^{51}$ and RAMANGASOAVINA stressed that the concept of international crimes would entail not only reparation but also sanctions. ${ }^{52}$

It must be pointed out, in this connection, that under draft Article 30 countermeasures constitute one of the circumstances precluding wrongfulness and that under draft Article 5 paragraph 3 of Part Two all states other than the state breaching the international obligation, are regarded as 'injured State' with respect to international crimes. In 1984 RIPHAGEN, the successor to AGO as Special Rapporteur, submitted a draft Article 14 paragraph 1 of Part Two, which provides: "An international crime entails all the legal consequences of an internationally wrongful act and, in addition, such rights and obligations as are determined by the applicable rules accepted by the international community as a whole", together with a draft Article 15, which provides: "An act of aggression entails all the legal consequences of an international crime and, in addition, such rights and obligations as are provided for in or by virtue of the United Nations Charter". ${ }^{53}$ Put all together, these provisions make all states other than the state breaching the international obligation, injured states and authorize them to resort to 'legitimate countermeasures', including sanctions under Chapter VII of the United Nations Charter.

RIPHAGEN's draft Articles 14 and 15 entailed a lengthy discussion in the ILC, but in the end the Commission did not adopt them. The reason for the non-adoption was that many members considered it necessary to limit the scope

\footnotetext{
${ }^{49}$ YBILC 1976, Vol. I, pp. 59-60 para. 32.

${ }^{50}$ Ibid., p. 63 para. 16.

51 Ibid., p. 68 para. 7.

52 Ibid., p. 76 para. 26.

53 YbILC 1984, Vol. II, pp. 259-260 para. 1.
} 
of 'injured States' which were entitled to resort to countermeasures. UsHAKOV, for example, while recognizing the existence of obligations erga omnes, could not share the view that an international crime necessarily injured all states within the international community because not all the states were equally affected by the crime. When one state committed an act of genocide in its territory, he doubted that any other state could be regarded as injured party. ${ }^{54}$ Similarly, SINCLAIR could not believe that, if a Mediterranean state caused enormous damage to the coast of neighbouring states by marine pollution, a land-locked state on another continent had the same entitlement to claim reparation as those neighbours did..$^{55}$ To MAHIOU the crime of aggression did affect the direct victim more seriously than other states. Though it would be difficult to determine how states were injured differently, he considered that a hierarchy of injurious consequences of internationally wrongful acts should be taken into account in determining their legal effects. ${ }^{56}$

The necessity to limit the scope of injured states implies the necessity to re-examine the concept of an international crime as stipulated in draft Article 19. During the ILC's discussion of draft Article 19 in 1976, TAMMES expressed some hesitation to the use of the term 'international crime' for an act of a state because the term had been used to describe acts of an individual in the Commission's Draft Code of Offenses against the Peace and Security of Mankind. He was not at all certain that international legal thinking had already evolved to the extent as to make such classification feasible. ${ }^{57}$ Likewise, KEARNEY noted that an author quoted in the Special Rapporteur's report regarded a regime of racial discrimination as an international crime, which would authorize the third state to resort to reprisals against its perpetrator. Since that would allow large states to intervene in the affairs of small states, he advised the Commission to take a cautious approach to the question of international crimes. ${ }^{58}$ Already in 1970, when the ILC discussed AGO's second report, REUTER pointed out that the problem of penal (criminal) responsibility might be called the problem of sanctions, that the term sanction applied to punishment as well, and that punishment came under a special regime as opposed to a general regime which the Commission should study first. ${ }^{59}$

It is noteworthy that SiMMA, while appreciating as a sign of progress the introduction of the concept of international crimes in the ILC's draft on state responsibility, warns against the danger of new conceptions making headway

\footnotetext{
54 Ibid., Vol. I, p. 277 para. 4.

${ }^{55}$ Ibid., p. 304 para. 6.

${ }^{56}$ Ibid., p. 128 para. 5.

57 YbILC 1976, Vol. I, p. 64 paras. 23-24.

${ }^{58}$ Ibid., p. 77 paras. 36-37.

59 YbILC 1970, Vol. I, p. 187 para. 4.
} 
in the absence of simultaneous progress in institution-building within the international community ${ }^{60}$ In any event ARANGIO-RUIZ, the current Special Rapporteur on state responsibility, proposed in his fifth report that: (1) the Commission should reconsider the problematic features of the formulation of draft Article 19 on second reading; (2) it should also reconsider the propriety of a clear-cut dichotomy between 'crimes' and 'delicts'; and (3) it should update the list of examples of international wrongful acts constituting international crimes, provided that such listing was desirable. ${ }^{61}$

\subsubsection{Relation between Obligation of Conduct and Obligation of Result}

The ILC divides international obligations of a state into three types according to their content: obligations to adopt a particular conduct, obligations to achieve a specified result, and obligations to prevent the occurrence of a given event. Thus, draft Article 20 provides, "There is a breach by a State of an international obligation requiring it to adopt a particular course of conduct when the conduct of that State is not in conformity with that required of it by that obligation". Similarly, draft Article 21 paragraph 1 provides: "There is a breach by a State of an international obligation requiring it to achieve, by means of its own choice, a specified result if, by the conduct adopted, the State does not achieve the result required of it by that obligation". Furthermore, draft Article 23 provides: "When the result required of a State by an international obligation is the prevention, by means of its own choice, of the occurrence of a given event, there is a breach of that obligation only if, by the conduct adopted, the State does not achieve that result".

The provisions are again general and abstract and raise two problems: first, in practice there are a number of cases where it is difficult to determine to which of the three types a particular obligation belongs. Another problem is: why is it necessary to divide a state's obligations into the three types and what practical merits does such division entail? ${ }^{62}$

\footnotetext{
${ }^{60}$ B. SIMMA, 'Bilateralism and Community Interest in the Law of State Responsibility', in Y. DinsteIn (Ed.), International Law at a Time of Perplexity (Dordrecht: Martinus Nijhoff, 1989) p. 844.

${ }^{61}$ Report of the ILC on the Work of its Forty-Fifth Session (A/48/10), paras. 329-331.

${ }^{62}$ It is clear from the formulation of Article 23 that the obligation to prevent the occurrence of a given event falls under the larger obligation to achieve a specified result. Therefore, the problem is if it is always possible to classify an international obligation of a state as either an obligation of conduct or an obligation of result and what practical merits such classification entails.
} 
AGO's draft of these three articles was, in essence, similar to the one adopted by the Commission. ${ }^{63}$ When the draft articles were discussed by the ILC in 1977, many members were critical of the division of obligations into the three types and, in particular, the division between obligations of conduct and obligations of result. For example, VEROSTA wondered whether such a division was valid in all cases and referred to the difficulty of categorizing the obligation to protect diplomatic missions or agents: was there a breach of an obligation of conduct or of result in the event of an assault on a diplomatic agent if the receiving state had done its best to prevent such assault? ${ }^{64}$ Likewise, QUENTIN-BAXTER was concerned if every international obligation could be classified as either of the two. For him, the obligation of a coastal state to guarantee the right of innocent passage as well as the obligation under the 1949 Geneva Conventions to punish perpetrators of 'grave breaches' could have the characteristics of both types of obligations. ${ }^{65}$ EL-ERIAN expressed his doubt about AGO's classification of a state's obligation to protect aliens as that of result because it could be described as an obligation of conduct as well. ${ }^{66}$ SAHOVIC pointed out that, even in the case of draft Article 20 dealing with obligations of conduct, what ultimately mattered was the result. Therefore, he was not certain what importance should be attached to the distinction between the result aimed at by an international obligation and the means to be used to achieve that result. ${ }^{67}$

Theoretically, it is not impossible to distinguish between an obligation of conduct and an obligation of result. However, as illustrated by the discussion in the Commission, the application of this distinction in factual situations does raise a number of difficulties. The 1965 International Convention on the Elimination of All Forms of Racial Discrimination, whose provision of Article 2 paragraph 1 (c) is quoted in the Commission's commentary as a case of an obligation of conduct, affords a good example. ${ }^{68}$ Article 2 paragraph 1(c) provides: "Each State Party shall take effective measures to review governmental, national and local policies, and to amend, rescind or nullify any laws and regulations which have an effect of creating or perpetuating racial discrimination [. . .]". Thus, a state party with a law of apartheid is obliged to amend or repeal it, which is seemingly a case of an obligation of conduct. But, seen in wider context, amendment or repeal of the law in question is one

\footnotetext{
${ }^{63}$ YbILC 1977, Vol. II Pt. One, p. 8 para. 13 and p. 20 para. 46; YbILC 1978, Vol. II Pt. One, p. 37 para. 19.

${ }^{64}$ YbILC 1977, Vol. I, p. 231 para. 17.

${ }^{65}$ Ibid., p. 224 paras. 3-5.

${ }^{66}$ Ibid., p. 225 para. 15.

${ }^{67}$ Ibid., p. 220 para. 16.

${ }^{68}$ YbILC 1977, Vol. II Pt. Two, p. 15 para. 11.
} 
of the means to eliminate racial discrimination, which is the very objective of the convention as a whole and is obviously an obligation of result.

Of course, it can be maintained that an obligation of result differs from an obligation of conduct in that, while the former allows a state to choose the means to attain an end, the latter does not allow such choice. ${ }^{69}$ However, the case quoted above clearly indicates that an obligation of result can be implemented only through an obligation of conduct. At the same time, as pointed out by SAHOVIC, each obligation of conduct has its own objective and, if that objective is seen in wider context, an obligation of conduct may be construed as consisting of a series of minor obligations of conduct. In fact, the ILC's commentary on draft Article 20 admits that a question of interpretation may arise as to whether a particular obligation of international law is of one type or another and that this should be settled by an international tribunal. ${ }^{70}$

It must be asked, then, why it is necessary to distinguish between the two types of obligations and for what practical merits. The same commentary emphasizes that the distinction between an obligation of conduct and that of result is important in determining when and how the breach of each of these obligations occurs. In other words, the conditions in which an international obligation is breached vary according to whether the obligation requires the state to take some particular actions or only requires it to achieve a certain result, while leaving it free to choose the means of doing so. ${ }^{71}$ This question will be analyzed in the following sub-section.

\subsubsection{Moment and Duration of the Breach of an International Obligation by a 'Complex Act'}

The ILC's draft Articles 24 to 26 deal with the time factor in case of breach of international obligations. In those Articles, acts of a state which constitute a breach of its international obligation are divided into those extending in time and those not extending in time. The former type of acts is further divided into 'composite acts', consisting of a series of actions or omissions in respect of separate cases, and 'complex acts', consisting of a succession of actions or omissions by the same or different organs of a state. However, with regard to the provisions concerning the moment and duration of the breach of an international obligation by a complex act, the following

\footnotetext{
${ }^{69}$ Ibid., pp. 13-14 para. 8 .

70 Ibid., p. 13 para. 4.

71 Ibid., p. 13 para. 5.
} 
problem arises which relates to the distinction between an obligation of conduct and an obligation of result.

Draft Article 18 paragraph 5 provides: "[T]here is a breach of [an] international obligation if the complex act not in conformity with it begins with an action or omission occurring within the period during which the obligation is in force [. . .], even if that act is completed after that period". But, according to draft Article 25 paragraph 3, the breach of an international obligation by a complex act occurs "at the moment when the last constituent element of that complex act is accomplished", and the time of breach "extends over the entire period between the action or omission which initiated the breach and that which completed it". As an illustration of such a situation, the commentary states that:

"if an international obligation of conventional origin requires the State to allow the nationals of a given foreign country to practice a particular profession, and if the administrative authority dealing with an application to practice that profession rejects the applications [sic], the rejection is not in itself a definitive breach of the international obligation in question. It will not be possible to conclude that such a breach exists so long as the result required by the obligation can still be achieved, either by review of its initial decision by the same authority, or by rescission or alteration of that decision by a higher authority."

In other words, the breach occurs only when the final decision, administrative or otherwise, of the state is reached by which the foreign national is ultimately refused to practice the profession, and the duration of the breach extends from the time of the initial rejection to that of the final refusal.

All in all, however, the provisions of the draft articles concerning the moment and duration of the breach of an international obligation by a complex act are extremely complicated and somewhat contradictory, and the complication as well as the contradiction seems to derive, at least in part, from the premise that a complex act is linked to an obligation of result. The commentary quoted above clearly explains that the breach of the obligation comes into existence only when the result required by the obligation is not achieved by the last of a succession of actions by the state organ concerned. ${ }^{73}$ Nevertheless, the illustration provided by that commentary can be more easily explained by linking a complex act with an obligation of conduct. Suppose that the conventional obligation of the state to allow foreign nationals to practice a particular profession constitutes an obligation of conduct, then its breach

22 YbILC 1976, Vol. II Pt. Two, p. 94 para. 23.

${ }^{73}$ Ibid. 
occurs at the moment when the administrative organ rejects a foreign national's initial application. The subsequent refusal by the higher organs is merely to confirm the first rejection and the amount of damage caused to the applicant is to be calculated from the moment of rejection of the initial application. As a result, it is not necessary to distinguish the moment of breach from the duration of breach.

Again, suppose that the treaty in question is amended in order to exclude foreign nationals from practising that profession before the application has reached the final stage, then it would be difficult to explain the situation under the premise that a complex act is linked with an obligation of result. True, draft Article 18 paragraph 5 provides that the breach of an international obligation by a complex act begins with the initial action or omission of that act occurring within the period during which the obligation is in force, even if the complex act is only completed after that period. However, since under Article 25 paragraph 3 the breach of an international obligation by a complex act is deemed to occur at the moment when the last constituent of that complex act is accomplished, there is no such occurrence if the obligation at issue is no longer in force at that moment. Besides, the basic premise of draft Article 18 paragraph 1 stipulates: "An act of the State which is not in conformity with what is required of it by an international obligation constitutes a breach of that obligation only if the act was performed at the time when the obligation was in force for that State".

Having scrutinized the provisions of the ILC draft articles on the time factor, KARL considers that there is a certain inconsistency in wording as far as the 'time of commission' of the complex act is concerned. ${ }^{74}$ In the view of SALMON, the notion of complex act is not only confusing but also dangerous and useless. ${ }^{75}$ KATO suspects that the concept of a complex act as well as the distinction between an obligation of conduct and an obligation of result was introduced in order to vindicate AGO's doctrine on the nature of local remedies in international law. ${ }^{76}$ It is true that the ILC's draft Article 22 stipulates, "When the conduct of a State has created a situation not in conformity with the result required of it by an international obligation concerning the treatment to be accorded to aliens, [. . .] there is a breach of the obligation only if the aliens concerned have exhausted the effective local remedies available [ . .]".

\footnotetext{
${ }^{74}$ W. KARL, 'The Time Factor in the Law of State Responsibility', in M. SPINEDI and B. SIMMA op.cit. n. 6.

75 J.J.A. SALMon, 'Le fait étatique complexe: une notion contestable', 28 Annuaire Francais de Droit International (1982) p. 738.

${ }^{76}$ N. KaTO, 'Kokunaiteki Kyusai Censoku no Hoteki Seikaku to (Fukugou Koui)' [The legal nature of the principle of exhaustion of local remedies and complex act]", 90 Kokusai-ho Gaikou Zasshi [Journal of International Law and Diplomacy], No. 6 (Feb. 1992) p. 26.
} 
This draft Article qualifies the international obligation concerning the treatment of aliens as an obligation of result. On the other hand, there has been a long-standing controversy between the doctrine which regards the requirement of exhaustion of local remedies as a substantive rule and that which regards it as a procedural rule, and AGO has been an ardent advocate of the latter. ${ }^{77}$

While this paper will not enter into an elaborate analysis of the criticism on the concept of a complex act, yet reference should be made to REUTER's remarks during the ILC's discussion in 1977 when draft Article 22 was first introduced. To REUTER the introduction of the provision on exhaustion of local remedies was confusing because, while the issue of exhaustion of local remedies related to the treatment of aliens, the ILC had earlier decided to deal, not with specific rules of state responsibility concerning treatment of aliens, but with general rules governing responsibility of states for any wrongful act. ${ }^{78}$

\section{SOME CONCLUDING OBSERVATIONS}

This paper has made an attempt to point to some problems concerning the basic premises, as well as the content, of the draft articles of Part One of the ILC's codification work on the topic of state responsibility. We submit that the ILC's premise to deal with general rules on the topic by focusing on what is termed 'secondary rules' has lead to the adoption of rather general and abstract rules. We also submit that the ILC's other premise of distinguishing responsibility for wrongful acts from liability for lawful acts is not free from problems. Furthermore, we have concluded that the distinction between international crimes and international delicts as well as its relevance to the provisions of Part Two is not necessarily clear. Similarly, the division of international obligations into obligations of conduct and obligations of result and, in that connection, the relevance of the concept of a complex act are not convincing.

Perhaps, these problems were bound to arise once the Commission decided to deal with general rules governing state responsibility for any wrongful act. As noted above, codification of exclusively secondary rules as detached from corresponding primary rules concerning the topic of international responsibility of states is likely to entail an enumeration of general and abstract provisions. In that sense the ILC might reconsider its approach to the topic and start codifying rules of state responsibility in a limited, specific field such as the treatment of aliens. The Commission itself noted that there has been sufficient

\footnotetext{
${ }^{77}$ See R. AGo, 'Le délit international', 68 RdC (1939-II) pp. 14-17.

${ }^{78}$ YBILC 1977, Vol. I, pp. 259-260 paras. 8-9.
} 
accumulation of state practice in this field. ${ }^{79}$ Also, state practice has not been insufficient in such other fields as international rivers, good neighbourliness and marine pollution. In addition, new practices are developing in the field of state activities in outer space as well as in the field of environmental protection. After successful codifications of rules on state responsibility in various specific fields, there may emerge a consensus of the international community to codify some general and probably basic rules on state responsibility covering all fields of international law. It is highly doubtful if the ILC's work on state responsibility has been based on such a consensus.

This does not mean that the ILC's work on state responsibility has been entirely useless. On the contrary, the provisions of draft articles in Chapter II of Part One concerning 'attribution' have successfully clarified several controversial problems such as the attribution of ultra vires conduct of state organs or of conduct of organs of a federal unit. ${ }^{80}$ Besides, the voluminous commentary attached to each draft article provides practitioners and academicians with an impressive array of materials on which to develop their analysis of wideranging questions on state responsibility. In evaluating some thirty-years' work of the ILC on the topic of international responsibility of states, the following observation by ZEMANEK is indeed suggestive:

\begin{abstract}
"For the codification of controversial rules of customary law it is [. . .] suggested to introduce an intermediate step, more persuasive than authoritative, between custom and convention. That intermediate step should essentially function as a device for building a new consensus. Instruments less stringent than treaties, such as declarations, restatements or codes should be used according to the state of the rules which they incorporate. They could also be arranged in a sequence, gradually edging States into conforming their actions and expectations to the proposed rules and thereby paving the way for a successful convention at a later stage. This is admittedly a slow and perhaps frustrating process. Yet it seems more promising than the adoption of a still-born codification convention for the archives of chancelleries."
\end{abstract}

\footnotetext{
${ }^{79}$ See supra.

${ }^{80}$ See the provisions of draft Art. 7 para. 1 and Art. 10.

${ }^{81} \mathrm{~K}$. ZEMANEK, 'Codification of International Law: Salvation or Dead End?', in Le droit international à l'heure de sa codification: Études en l'honneur de Roberto Ago (Milano: Dott. A. Giuffré, 1987) 600-601.
} 